
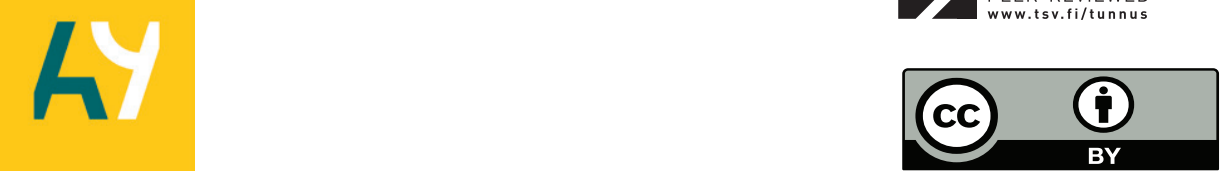

Anna Emilia Hellén ${ }^{a}$

\title{
Kielimaiseman vaikutus maahanmuuttajien liikkuvuuteen pääkaupunkiseudulla
}

\begin{abstract}
The impact of the linguistic landscape on the mobility of immigrants in Helsinki region We are surrounded by language, both spoken and written, in our daily life. Written information can be seen in shop windows, advertisements and street signs while walking along the street. Normally we don't pay much attention to the amount of written language there is in our surroundings, as we process the written information automatically in passing. The situation is completely different if the linguistic landscape is unknown to us. In this article the impact of the linguistic landscape on the mobility of illiterate immigrants is examined in the Helsinki metropolitan area of Finland. Solutions to improve the linguistic accessibility of the urban environment are examined by interviewing immigrants who reside in the Helsinki region.
\end{abstract}

Keywords: linguistic accessibility, urban planning, mobility, linguistic landscape, urban space

\section{Johdanto}

Yleisen globalisaation myötä Suomi on viimeisen kahden vuosikymmenen aikana monikulttuuristunut kasvavalla vauhdilla (Nieminen 2011; Salmela 2012, 27; Toivonen 2013, 12). Lähi-Idän sekä Afrikan maiden kriisien myötä myös Suomeen on suuntautunut muun Euroopan tavoin turvapaikanhakijoiden virta (Sisäministeriö 2017). Jopa 65 prosenttia kaikista Suomen ulkomaalaistaustaisista henkilöistä asuu kymmenessä suurimmassa kaupungissa (Väestöliitto 2017). Vuonna 2016 Suomen väestöstä ulkomaalaistaustaisia oli 364787 henkilöä, eli 6,6 prosenttia (Tilastokeskus 2017), kun vielä vuonna 2014 osuus oli noin 4 prosenttia (Väestöliitto 2017). Vieraskielisiä (muu kuin suomi, ruotsi tai saame) oli vuoden 2016 lopussa yhteensä 6,4 prosenttia koko väestöstä (Tilastokeskus 2017). Ulkomaalaistaustaisten ja vieraskielisten henkilöiden osuus tulee todennäköisesti lisääntymään myös jatkossa kantaväestön vanhenemisen ja syntyvyyden alenemisen sekä toisaalta maahanmuuton jatkumisen myötä (Nieminen 2011, 6).

Maahanmuuttajat eivät ole homogeeninen ryhmä. Heidän sosioekonomiset taustansa ja maahanmuuton syyt vaihtelevat. Terveyden ja hyvinvoinnin laitoksen teettämän tutkimuksen mukaan 40 prosentilla Suomeen tulevista maahanmuuttajista on korkeakoulututkinto ja noin 25 prosentilla on peruskoulututkinto (THL 2017). Osalla saattaa olla hyvä englannin kielen taito, jonka avulla he voivat kohdemaassaan tulla toimeen. Osa Suomeen saapuneista maahanmuuttajista on voinut aloittaa suomen tai ruotsin kielen opiskelun esimerkiksi jo pakolaisleireillä. Muuttovirtojen mukana Suomeen saapuu kuitenkin myös henkilöitä, jotka eivät

a Humanistinen ammattikorkeakoulu, anna.e.hellen@outlook.com 
kotimaassaan ole käyneet kouluja lainkaan, eivätkä he välttämättä osaa maahan saapuessaan lukea, kirjoittaa tai tunnistaa latinalaista aakkosjärjestelmää (Linderborg 2008, 27-28). Kohdemaan kielen osaamattomuus voi aiheuttaa heille vaikeuksia sopeutua uuteen yhteiskuntaan, mikä saattaa johtaa muun muassa eristäytymiseen ja masennukseen. Kotoutumisvaikeuksien taustalla voivat olla vaikeudet osallistua yhteiskunnan toimintoihin, joihin kuuluvat muun muassa kielikurssit, työ ja muut yhteisölliset aktiviteetit. Myös syrjintä ja sosiaalisten verkostojen puuttuminen ylläpitävät kotoutumisen estymisen riskiä (Salmela 2012, 33; Toivonen 2013, 29; THL 2017). Kielellisten esteiden vähentäminen on ensimmäinen askel uuteen yhteiskuntaan kotoutumisessa.

Maantieteellinen tutkimus tilasta, ja varsinkin julkisesta kaupunkitilasta, on keskittynyt enimmäkseen sosiaaliseen inkluusioon, sosiokulttuurisiin rakenteisiin, tilan kokemuksiin, tilaan liittyviin pelkoihin sekä osallistamiseen (esim. Lefebvre 1991; Koskela 1995; Williams \& Van Der Merwe 1996; Harvey 2003). Maantieteellisen keskustelun keskiössä on ollut pohdinta kaupunkitilan haltuun ottamisen oikeudesta ja viime vuosien aikana saavutettavuuteen ja liikkuvuuteen liittyvät teemat ovat myös tulleet suosituiksi. Kaupunkitilojen kielimaisema ja -politiikka on kuitenkin jäänyt keskusteluissa vähemmälle huomiolle. Kielimaisemalla (linguistic landscape) tarkoitetaan sitä maisemaa, tilaa tai näyttämöä, joka muodostuu katualueista, aukioista, puistoista ja rakennuksista, eli alueista ja tiloista, joissa julkista elämää esiintyy (Ben-Rafael ym. 2006) ja johon kieli oleellisena osana liittyy merkitysten, näkyvän kirjoituksen sekä puheen muodossa. Kielimaiseman vaikutusta vieraasta kielellisestä ympäristöstä tulevien henkilöiden liikkuvuuteen ei ole juurikaan tarkasteltu näiden edellä mainittujen teemojen yhteydessä kansallisissa eikä kansainvälisissäkään julkaisuissa. Tämän artikkelin tarkoituksena onkin avata maantieteellistä ja kaupunkitutkimuksellista keskustelua kielimaiseman vaikutuksesta heikon kielitaidon omaavien maahanmuuttajien kokemuksiin kielellisestä ympäristöstä, liikkumisesta, sekä uuteen yhteiskuntaan sopeutumisesta. Kielimaiseman ja maahanmuuttajien liikkuvuuden välisen yhteyden ymmärtäminen auttaa suunnittelemaan kielellisesti saavutettavampia kaupunkiympäristöjä. Näin mahdollistetaan myös sosiaalisen oikeudenmukaisuuden toteutuminen kaikille kaupungissa asuville ja vieraileville ihmisille.

Tässä artikkelissa tarkastellaan kielellisen kaupunkiympäristön vaikutusta suomea tai ruotsia heikosti tai ei lainkaan puhuvien maahanmuuttajien liikkumiseen ja kaupunkitilassa orientoitumiseen pääkaupunkiseudulla. Kiinnostuksen kohteena on tutkia, miten maahanmuuttajat liikkuvat ja navigoivat kaupunkiympäristössä ja miten he löytävät tarvitsemiinsa palveluihin, kun kielimuuri tulee vastaan ympäristössä. Kielimuurilla tarkoitetaan tässä artikkelissa tilannetta, jossa heikon kielitaidon omaava henkilö joutuu tilanteeseen, josta selvitäkseen tulisi osata kieltä. Esimerkkejä tällaisista tilanteista ovat palveluiden käyttö, avun pyytäminen vastaantulevilta natiivipuhujilta tai navigoiminen kartan avulla.

Tietoa liikkumisen strategioista vieraassa kielimaisemassa ja kielimaiseman vaikutuksesta liikkuvuuteen haetaan aiempia tutkimuksia tarkastelemalla ja pääkaupunkiseudulla asuvia heikon suomen tai ruotsin kielen taidon omaavia maahanmuuttajia haastattelemalla. Haastattelut on toteutettu puolistrukturoituina hasstatteluina ja apuna on tarvittaessa käytetty tulkkeja. Kirjallisuuskatsauksen ja haastatteluiden kautta selvitetään, mikä vaikutus kirjoitetulla kielellä on suunnistamiseen, sekä tutkitaan, millaisia strategioita on kaupungissa navigoimiseen, kun kielellisiä apuja on vähän. Aineistona tässä tutkimuksessa käytetään haastatteluissa tallennettuja ja litteroituja maahanmuuttajien kertomuksia kaupunkiympäristössä liikkumisesta.

Tutkimuskysymykset ovat seuraavat:

1) Millaisena erilaisista kieliympäristöistä Suomeen saapuneet maahanmuuttajat kokevat ympäröivän kaupunkitilan?

2) Millaisia liikkumiseen liittyviä ongelmia vieraaseen kielimaisemaan tulleilla maahanmuuttajilla on?

3) Millaisia keinoja maahanmuuttajat käyttävät ratkaistakseen kaupungissa liikkumiseen liittyviä ongelmia? 
Hakemalla vastauksia näihin kysymyksiin voidaan myös vastata siihen, millaisia modifikaatioita olemassa oleviin karttoihin tai viranomaisten antamiin ohjeistuksiin pitäisi tehdä, jotta kaupungissa navigoimisen voisi tehdä maahanmuuttajille helpommaksi.

\section{Kaupunkitilan kokeminen ja tilan saavutettavuus}

Kaupungissa kulkiessamme olemme yhteydessä ympäröivään kaupunkitilaan. Tila on käsitteenä keskeinen halutessamme ymmärtää ihmisten kokemuksia ympäröivästä maailmasta. Tilan ymmärtämiseen liittyvät yksilön aiemmat kokemukset, tiedot ympäröivästä tilasta sekä kulttuurinen tausta eli tilan ymmärtäminen ja kokeminen ovat lähtökohtaisesti yksilöllisiä kokemuksia.

Henry Lefebvre selittää tilaa kolmella tavalla: tila todellisuuden representaationa eli suunniteltuna fyysisenä tilana; tila spatiaalisten käytäntöjen areenana eli havaittuna ja elettynä tilana; sekä tila representaatioiden näyttämönä eli kokemuksina eletystä ja ymmärretystä tilasta (Lefebvre 1991; Johnson \& Miles 2014). Näiden tilan ulottuvuuksien tulisi olla harmoniassa keskenään, jotta tilassa liikkuvalla ja toimivalla henkilöllä olisi turvallinen ja varma olo toimiessaan ympäristössään. Harmonialla tässä tarkoitetaan sitä, että suunniteltu fyysinen tila vastaa sitä käsitystä, mikä meillä ympäristöstämme on eli pystymme havaitsemaan ja ymmärtämään ympäristömme sellaisena, kuin millaiseksi se on suunniteltu ja rakennettu. Tätä kautta pystymme myös toimimaan meiltä oletetulla tavalla.

Julkinen tila on lähtökohtaisesti julkinen resurssi, johon kaikilla tässä tilassa liikkuvilla pitäisi olla nautintaoikeus (Harvey 2003). Julkisessa kaupunkitilassa tilan eri ulottuvuudet eivät kuitenkaan aina ole yksilön näkökulmasta katsottuna harmoniassa keskenään, vaan julkisessa kaupunkitilassa esiintyy myös tilan haltuunottoon ja omistamiseen sekä julkisten resurssien jakoon liittyviä tilallisia konflikteja, jotka asettavat kaupunkitilasta nauttivat ihmiset toisiinsa nähden eriarvoiseen asemaan (Harvey 2003; Neely \& Samura 2011; Johnson \& Miles 2014). Konflikteja ja tilaan liittyviä valtakamppailuja syntyy esimerkiksi siitä, kun nämä mainitut tilan kolme eri ulottuvuutta ovat toistensa suhteen ristiriidassa yksilön taidoista tai kokemuksista tai tilassa esiintyvistä sosiaalisista rakenteista johtuen. Yksi esimerkki tilassa esiintyvästä konfliktista on, kun tilan representaatio eli fyysinen tila on ristiriidassa yksilön taitojen ja kykyjen kanssa. Tämän seurauksena tilankäyttöön liittyvien yleisten käytäntöjen seuraaminen muodostuu hankalaksi, mikä vaikuttaa yksilön kokemuksiin eletystä ja ymmärretystä tilasta. Erilaisen kulttuurisen taustan omaavalla maahanmuuttajalla on juuri tällainen tilanne vastassaan hänen muuttaessaan uuteen maahan, kulttuuriin ja kielimaisemaan. Kaupunkiympäristön representaatio, jossa tekstin rooli on merkittävä ( $\mathrm{mm}$. katukyltit, opasteet ja kartat), saattaa aiheuttaa lukutaidottomalle maahanmuuttajalle vaikeuksia toimia tekstien esittämällä tavalla. Maahanmuuttajalla ei siis silloin ole samoja taitoja kuin muilla samassa tilassa toimivilla henkilöillä. Tämä johtaa siihen, ettei vieraaseen kielimaisemaan saapunut henkilö pysty toteuttamaan tilaan liittyviä käytäntöjä, eli esimerkiksi toimimaan opasteiden, ohjeiden tai katukylttien osoittamalla tavalla, eikä hän näin ollen pysty ottamaan tilaa haltuunsa samalla tavalla kuin muut samassa tilassa liikkuvat henkilöt. Tällöin kyseinen henkilö ei myöskään koe omistavansa tai olevansa osa tätä tilaa. Sen sijaan hän voi aiempien kokemustensa ohjaamana toimia täysin päinvastaisesti, kuin miten muut samassa tilassa olevat henkilöt toimivat, ja saada tästä myös negatiivista palautetta. Tällaisista tilanteista voi seurata negatiivisen kokemuksen muodostuminen ympäröivästä tilasta. (Neely \& Samura 2011). Jos julkinen tila on rakennettu siten, etteivät kaikki samassa tilassa liikkuvat ja toimivat pysty siitä nauttimaan, muodostuu konflikti julkisten resurssien jaolle. Tällöin ei myöskään tilan haltuunoton ja omistamisen mahdollisuus jakaudu kaikille julkisessa tilassa toimiville tasaarvoisesti.

Saavutettavuus (accessibility) on yksi julkisen tilan keskeisimmistä fyysisistä ulottuvuuksista, jonka kautta kaupunkitilan käyttäjillä on mahdollisuus osallistua yhteiskunnan tarjoamiin palveluihin ja toimintoihin (Johnson \& Miles 2014). Saavutettavuudella tarkoitetaan resurssien, palveluiden ja infrastruktuurin saatavuutta ja sitä mitataan usein ihmisten ja tilassa olevien objektien välisenä suhteena ja yhteytenä (Yu 2016). Saavutettavuutta on kirjallisuudessa käsitelty useimmin fyysisenä saavutettavuutena, etäisyyksinä, aikatilana ja kustannuksina (esim. Geurs 
\& van Wee 2004; Kuisma 2017, 9), mutta kognitiivista saavutettavuutta erityisesti kielellisestä näkökulmasta katsottuna on käsitelty vain vähän.

Hyvä palveluiden ja erilaisten muiden toimintojen saavutettavuus on sosiaalisen oikeudenmukaisuuden, yhteiskunnallisen osallisuuden ja kotoutumisen kulmakivi. Se mahdollistaa liikkumisen ja on edellytys liikkuvuudelle (Johnson \& Miles 2014; Yu 2016). Liikkuvuudella (mobility) tarkoitetaan kykyä liikkua, liikkumiseen johtavia ja sen aikana tehtyjä päätöksiä sekä kitkaa liikkujan ja toteutuneen liikkuvuuden välillä (Yu 2016; Kuisma 2017, 8-9). Hyvä saavutettavuus ei kuitenkaan tarkoita liikkuvuuden toteutumista (Yu 2016; Kuisma 2017, 14-15). Tutkimusten mukaan kielitaidottomuus voi olla yksi este maahanmuuttajien liikkuvuudelle (Chang 2013, 2015; Johnson \& Miles 2014; Vaittinen \& McGookin 2016). Heikko kielitaito ja sen aiheuttama pelko liikkua ennestään tuntemattomille alueille tai käyttää uusia kulkuvälineitä tai joukkoliikennelinjoja vähentävät maahanmuuttajien liikkuvuutta (Chang 2013; 2015) ja estävät heitä nauttimasta samoista resursseista ja palveluista kuin kyseisen maan kieltä osaavat kaupunkitilan käyttäjät. Tällöin ei sosiaalinen oikeudenmukaisuuskaan toteudu.

Sosiaalisen oikeudenmukaisuuden toteutuminen on kaupunkisuunnittelussa keskeinen vaatimus. Sosiaalisella oikeudenmukaisuudella tarkoitetaan yhtäläistä mahdollisuutta ja vapautta käyttää palveluita ja julkisia resursseja, mikä vaatii hyvää saavutettavuutta (Talen 2002). Julkisen tilan rakenteilla on suuri merkitys siihen, miten sosiaalinen ja poliittinen organisoituminen tilassa tapahtuu sekä millainen saavutettavuus tilassa muodostuu. Suunnittelussa tuleekin siksi ottaa vähemmistöryhmien kokemukset huomioon, jotta sosiaalinen ja ympäristöllinen oikeudenmukaisuus toteutuisi julkisessa tilassa (Liu \& Schachter 2007; Tal \& Handy 2010). Maahanmuuttajien liikkuvuuteen liittyviä ongelmia sekä suunnistamisen ja liikkumisen strategioita ymmärtämällä voidaan kehittää tehokkaampia apuja navigoinnin tueksi ja tämän kautta edistää liikkuvuuden ja sosiaalisen oikeudenmukaisuuden toteutumista julkisessa kaupunkitilassa.

\section{Liikkuvuus ja navigoinnin strategiat vieraassa kielimaisemassa - katsaus tietoperustaan}

Kielimaiseman analyyseissä keskitytään yleensä tilaa jäsentävien symbolisten käytäntöjen ja valtasuhteiden tutkimiseen sekä siihen, millä tavalla ihmiset käyttävät kielellisiä symboleja antaessaan merkityksiä ympäristöstään. Niissä ei kuitenkaan ole otettu kantaa kielimaiseman vaikutukseen liikkuvuuteen, varsinkaan kyseistä kieltä osaamattomien maahanmuuttajien näkökulmasta. Kiinnostuksen kohteena kielimaiseman tutkimusalalla on sen sijaan ollut tutkia sekä instituutioiden että yksilöiden käyttämiä kielellisiä symboleja (Ben-Rafael ym. 2006). Perinteisesti kielimaisemaa tarkastellaan kielitieteellisestä näkökulmasta yksinkertaisesti tutkimalla julkisissa tiloissa käytettyä kirjoitettua kieltä (Gorter 2006; Nash 2016), mutta Nashin (2016) mielestä tästä tulisi edetä tutkimaan myös kielimaiseman vaikutusta ihmisten liikkuvuuteen, kielen vaikutusta tilan kokemukseen sekä identiteetin muodostumisen ja ympäristön väliseen interaktioon.

Liikkuvuusaiheisissa kognitio- ja kielitieteellisissä tutkimuksissa on tarkasteltu ihmisten suunnistamisen taitoja vieraassa ympäristössä. Nämä tutkimukset keskittyvät maamerkkien tunnistamiseen (Denis ym. 1999; Richter \& Winter 2014), kognitiivisten karttojen muodostumiseen (Hölscher ym. 2011; Chang 2015), reittiohjeiden antamiseen (esim. Levinson 1996) sekä eri navigoinnin apuvälineiden tehokkuuteen uuteen kohteeseen suunnistettaessa (esim. Hölscher ym. 2011). Edellä esitellyissä tutkimuksissa on tarkasteltu kielen merkitystä navigoinnissa reittiohjeiden ja suunnistamisen vihjeiden muodossa eli muodostuvatko reittiohjeet osoitteista ja kadunnimistä vai kuvauksina maamerkeistä (esim. Tom \& Denis 2004). Kielitieteissä on lisäksi tarkasteltu kielenkäyttöön liittyviä kulttuurisia eroavaisuuksia reittiohjeiden antamisessa (esim. Kitson, Sproll \& Riecke 2016). Tutkimusten pääpaino on kuitenkin liittynyt kaupunkiympäristön visuaalisuuteen sekä osallistuvien henkilöiden kognitiivisiin taitoihin sen sijaan, että olisi otettu kantaa kielimaiseman vaikutukseen arkipäiväiseen liikkuvuuteen, liikkuvuuteen johtaviin päätöksiin sekä suunnistamiseen.

Maahanmuuttajia on hyvin heikosti tutkittu kielimaiseman tutkimusalan sekä 
liikkuvuusaiheisissa tutkimuksissa. Maahanmuuttajien kohdalla tehdyissä tutkimuksissa on oltu kiinnostuneita ennemminkin kotoutumisprosessista, uuteen yhteiskuntaan integroitumisesta, (esim. MOST-project 2008; Nieminen 2011; Salmela 2012; Toivonen 2013), sekä sosiaalisista kokemuksista julkisessa tilassa (Nagel \& Staeheli 2004; Secor 2004; Johnson \& Miles 2014; Yu 2016). Kansainvälisestä kirjallisuudesta löytyy kuitenkin muutamia tutkimuksia maahanmuuttajien liikkumisesta sekä liikennevälineiden käytöstä (esim. Liu \& Schachter 2007; Tal \& Handy 2010), mutta aihetta ei ole käsitelty vielä perusteellisesti.

\section{Liikkuminen kaupunkiympäristössä ja kielimaiseman vaikutus navigoimiseen}

Tutuissa ympäristöissä liikkuminen ja navigointi tapahtuvat lähtökohtaisesti lihasmuistin, spatiaalisen tietouden sekä kognitiivisten karttoja avulla (esim. Allen 1999; Frankenstein ym. 2012; Ferretti ym. 2013; Parente 2016). Tuntemattomissa ympäristöissä on puolestaan turvauduttava erilaisiin navigointistrategioihin (Allen 1999; Wiener ym. 2009; Chang 2015). Tällaisissa tilanteissa navigoijan on mahdollista hyödyntää ympäristöstä tulevia vihjeitä, kuten viitoituksia, kylttejä, reittiohjeita tai karttoja, ja usein toteutunutta liikkumista on edeltänyt laaja tiedonhaku saavutettavasta kohteesta sekä reitistä määränpäähän (esim. Wiener ym. 2009). Ympäristöstä tulevat vihjeet, kuten esimerkiksi muilta ympäristössä liikkuvilta ihmisiltä saadut reittiohjeet, monien karttojen antama informaatio, netistä saatavat reittiohjeet sekä ympäristön viitoitukset ja kyltit, ovat useimmin kuitenkin luonteeltaan kielellistä informaatiota (Gale ym.1990; Hölscher ym. 2011; Parente 2016). Tällaisissa tilanteissa liikkuminen saattaa muodostua haastavaksi heikon kielitaidon omaaville navigoijille. Nykypäivän teknologia tosin auttaa kaupunkiympäristössä liikkumista, jos vieraassa ympäristössä liikkuvalla on saatavilla gpspaikannuksen kautta toimiva karttasovellus esimerkiksi puhelimessaan. Kyseisten sovellusten käyttö ei myöskään vaadi täydellistä kartanlukutaitoa, kun sovellus kertoo mihin suuntaan henkilön on käännyttävä. Kohteen osoite on kuitenkin pystyttävä kirjoittamaan sovellukseen ja perille päästyä on kohde pystyttävä tunnistamaan ympäristöstä.

Kielimaisemalla on tutkitusti vaikutusta vieraasta kielimaisemasta tulevien kokemuksiin heidän liikkuessaan kaupunkiympäristössä. Esimerkiksi Changin (2013; 2015) turistien keskuudessa tekemissä tutkimuksissa kävi ilmi, että vieras kielimaisema ja tuntematon ympäristö aiheuttavat turisteille stressiä ja eksymisen pelkoa, koska yhteisen kielen puuttuessa heillä on hankaluuksia kommunikoida ympärillä liikkuvien paikallisten kanssa. Erilaiseen kieliympäristöön joutuessaan turistit tunsivat olonsa levottomiksi, stressaantuneiksi, epämukaviksi ja pelokkaiksi. Myös paniikin kokemukset olivat mahdollisia. Levottomuuden kasvaessa suunnistamisessa tapahtuvat virheet ja navigointiin kulutettu aika kasvoivat. (Chang 2013; 2015). Tehtyjen tutkimusten mukaan hämmentyneisyys, pelokkuus ja eksymisen pelko kaupunkiympäristössä vähentävät ihmisten halukkuutta liikkua tuntemattomassa ympäristössä (Hund \& Minarik 2006; Chang 2013; 2015; Johnson \& Miles 2014). Useissa tutkimuksissa onkin painotettu symbolikielen lisäämistä kaupunkiympäristöihin saavutettavuuden ja kielellisen esteettömyyden parantamiseksi (esim. Chang 2015; Vaittinen \& McGookin 2016).

\section{Kielitaidon ja liikkuvuuden vaikutukset paikkaan kiintymiseen, kotoutumiseen ja kansalaiskäsityksen muodostumiseen}

Feministisessä ja postkolonialistisessa tutkimuksessa on selvitetty maahanmuuttajien kansalaiskäsityksen (citizenship) muodostumista. Kansalaisuus on sekä juridinen termi ja status että yksilöllinen tunne ja diskurssi yhteenkuuluvuudesta kulttuuriin, yhteiskuntaan ja yhteisöön. Lisäksi se käsittää sekä yhteenkuuluvuuden tunteen lajempaan urbaaniin yhteisöön että aktiivisen osallistumisen urbaaniin elämään. (Nagel \& Staeheli 2004; Secor 2004)

Secor (2004), Nagel ja Staeheli (2004) sekä Yu (2016) haastattelivat tutkimuksissaan uusia maahanmuuttajia Istanbulissa ja New Yorkissa. Haastateltavat mainitsivat kielimuurin yhdeksi suurimmaksi syyksi urbaanin kansalaisuuden muodostumisen esteeksi. Kielimuuri esti heitä liikkumasta tutun arkiympäristön ulkopuolelle sekä osallistumasta yhteiskuntaan sen täysivaltaisena jäsenenä. Tällöin heille ei myöskään muodostunut yhteenkuuluvuuden 
tunnetta tai spatiaalista käsitystä laajemmasta urbaanista ympäristöstä. Haastateltavien mukaan "urbanistumisessa" tärkeimpänä tekijänä on juuri kosketus paikalliseen kulttuuriin, paikallisiin asukkaisiin sekä omaan elinympäristöönsä. Useissa tutkimuksissa on myös tullut esille, että elinympäristön kielen osaamattomuus vaikuttaa paikkaan kiintymisen estymiseen (esim. Williams \& Van Der Merwe 1996; Hay 1998; Salmela 2012; Toivonen 2013). Tämän seurauksena maahanmuuttajat eivät tunne itseään kansalaisiksi, vaan he tuntevat itsensä ennemminkin muukalaisiksi uudessa kotimaassaan. Tämänkaltaisilla tunteilla on myös suuri vaikutus maahanmuuttajien mielenterveyteen. Yhteenkuuluvuuden ja kansalaisuuden tunteen puuttuminen voi maahanmuuttajien kohdalla johtaa kotoutumisen, yhteiskuntaan integroitumisen sekä uuteen ympäristöön kiintymisen viivästymiseen tai estymiseen täysin (Nagel \& Staeheli 2004; Linderborg 2008; Yu 2016). Yhteenkuuluvuuden tunne ja aktivoituminen urbaaniin elämään muodostuvat koulutuksen sekä liikkuvuuden kautta (Secor 2004; Yu 2016).

Heikko kohdemaan kielitaito nousee jo tehdyissä tutkimuksissa esille yhtenä tekijänä, joka vaikeuttaa maahanmuuttajien kohdalla yhteiskuntaan integroitumisen (esim. Nagel \& Staeheli 2004; Secor 2004; Salmela 2012; Toivonen 2013; Yu 2016). Heikko kielitaito ei ainoastaan vaikuta sosiaalisten suhteiden muodostamisen ja työpaikan löytämisen vaikeuteen, vaan sen on huomattu olevan myös psykologisena esteenä liikkuvuudelle. Maahanmuuttajat voivat kokea ympäröivän kaupunkiympäristön pelottavana ja epämukavana, koska heikon kielitaidon takia he eivät pysty ymmärtämään katuopasteita, kylttejä tai karttoja, eikä heillä ole mahdollisuutta pyytää reittiohjeita vastaantulijoilta (Secor 2004; Yu 2016). Maahanmuuttajilta ei kuitenkaan Yun (2016) mukaan puutu saavutettavuus palveluihin ja sosiaaliseen elämään, vaan liikkuvuus on ennemminkin puutteellista juuri psykologisten esteiden takia. Liun ja Schachterin (2007) mukaan tämä aiheuttaa epäoikeudenmukaisuutta, sillä maahanmuuttajilla ei ole heikon kielitaidon takia mahdollisuuksia saada samaa informaatiota esimerkiksi palveluiden tai joukkoliikenteen saatavuudesta kuin kielitaitoisilla kansalaisilla. Mahdollisuus liikkua ja löytää tie haluamiinsa kohteisiin on välttämätöntä jokapäiväisten toimintojen ja tarpeiden suorittamisessa (Hund \& Minarik 2006).

\section{Tutkimusmenetelmät ja aineisto}

Tutkimuksen empiirisessä osassa tutkitaan maahanmuuttajien navigoinnin haasteita pääkaupunkiseudulla. Edellä mainittu Lefebvren teoria tilan kolmesta ulottuvuudesta ohjaa tutkimuksen empiiristä osaa teoreettisena viitekehyksenä. Tarkoituksena on selvittää, miten sekä fyysisen tilan kielimaisema että fyysisen tilan rakenne vaikuttavat heikon kielitaidon omaavien maahanmuuttajien kokemuksiin eletystä ja ymmärretystä tilasta, sekä millaisena he havaitsevat tämän heitä ympäröivän tilan. Tähän pyritään haastattelemalla tutkimukseen osallistujia puolistrukturoidun haastattelun kautta fenomenologisella otteella sekä narratiivisen tutkimuksen keinoin.

Tutkimukseen osallistuvat rekrytoitiin Stadin aikuisopistosta sekä Helsingin kaupungin aikuislukiosta, jotka järjestävät suomen kielen kursseja muun muassa luku- ja kirjoitustaidottomille maahanmuuttajille. Tutkimukseen osallistuminen perustui vapaaehtoisuuteen. Tutkimuksen tarkoituksesta ja tavoitteista informoitiin osallistujia heidän omalla äidinkielellään.

Tutkimuksessa haastateltiin 16 erilaisista taustoista tulevaa maahanmuuttajaa, jotka osasivat suomea, ruotsia tai englantia heikosti tai eivät ollenkaan. Kielitaidon arvio perustui haastateltavan omaan arvioon. Osa haastateltiin ostopalveluna hankitun tulkin välityksellä, ilman tulkkia haastateltiin viisi suomeksi ja yksi englanniksi. Haastattelun alkupuolella haastateltava sai eteensä viiden kohdan asteikon, jossa hymiöin ja numeroin haastateltava sai arvioida, kuinka hyvin kokee pärjäävänsä tämän hetkisellä suomen, ruotsin tai englannin kielen taidolla arjessaan Suomessa. Numero 1 ja pohdiskeleva hymiö tarkoitti vaikeuksia toimia arjessa nykyisellä kielitaidolla ja numero 5 sekä hymyilevä hymiö tarkoitti, että kokee pärjäävänsä arjessa hyvin nykyisellä kielitaidolla. Suurin osa haastateltavista oli Suomeen tullessaan täysin luku- ja kirjoitustaidottomia, mutta monet heistä olivat haastatteluajankohtana jo hieman oppineet suomen kieltä. Suomeksi haastatellut olivat pääsääntöisesti asuneet Suomessa jo pidemmän aikaa, mutta heistäkin muutama mainitsi, että heillä on edelleen vaikeuksia toimia arjessaan vaikka ovat perussanastoa ja kielioppia jo oppineet. Tämä johtui haastateltujen 
henkilöiden mukaan siitä, ettei heillä ole tarpeeksi kontaktia suomea puhuviin henkilöihin, jotta heidän kielitaitonsa karttuisi. Kahden suomeksi haastatellun osallistujan kohdalla kävi haastattelun aikana ilmi, etteivät henkilöt ymmärtäneet kaikkia esitettyjä kysymyksiä edes kysymyksenasettelua muuttamalla. Kyseiset henkilöt eivät kysyttäessä kuitenkaan halunneet tulkkia mukaan haastatteluun. Yhteenveto tutkimukseen osallistuneista ja heidän taustoistaan on esitetty taulukossa 1 . Osallistujien nimet on muutettu.

Tutkimuksen haastattelurunko koostui yhdeksästä taustakysymyksestä ja 34 varsinaisesta kysymyksestä, jotka jakautuivat vielä neljään teemaan. Taustakysymyksissä selvitettiin haastateltavan ikä, sukupuoli, lähtömaa, äidinkieli, muu kielitaito sekä kuinka kauan henkilö on asunut Suomessa. Varsinaiset kysymykset liittyivät kielimaisemaan, palveluiden käyttöön, palveluiden saavutettavuuteen ja haastateltavan liikkuvuuteen sekä viranomaisten lähettämiin ohjeisiin. Näissä kysymyksissä kysyttiin esimerkiksi, miten henkilö muistaa reagoineensa vieraaseen kielimaisemaan tullessaan, onko henkilöllä ollut vaikeuksia liikkua kaupungissa vieraan kielen takia, millaisia palveluita henkilö käyttää ja millaisia palveluita hän haluaisi käyttää, mitä suunnistamisen apuvälineitä henkilö käyttää, miten hän löytää ennestään tuntemattomaan kohteeseen ja kuinka usein hasstateltava käy uusissa paikoissa.

Kaikkia kysymyksiä ei haastattelujen aikana käyty läpi, vaan haastattelut etenivät haastateltavan ohjaamana. Kysymyksiä käytettiin ohjaamaan keskustelua kohti toivottuja teemoja. Näin

Taulukko I. Osallistujien taustatiedot

Table I. Participants' background information

\begin{tabular}{|c|c|c|c|c|c|c|c|}
\hline Osallistuja & lkä & $\begin{array}{l}\text { Suku- } \\
\text { puoli }\end{array}$ & Lähtömaa & $\begin{array}{l}\text { Asunut } \\
\text { Suomessa } \\
\text { (vuotta) }\end{array}$ & $\begin{array}{l}\text { Kielitaito, } \\
\text { äidinkieli } \\
\text { (vahvin ensin) }\end{array}$ & $\begin{array}{l}\text { Oma arvio } \\
\text { suomen kielen } \\
\text { taidosta }(1-5)^{*}\end{array}$ & $\begin{array}{l}\text { Tulkki } \\
\text { haastattelussa }\end{array}$ \\
\hline Jawid & 21 & mies & Afganistan & 2 & dari, suomi & I & Kyllä \\
\hline Rashid & 23 & mies & Afganistan & 3 & $\begin{array}{l}\text { dari, farsi, } \\
\text { englanti, suomi }\end{array}$ & 3 & Kyllä \\
\hline Asim & 42 & mies & Irak & 3 & arabia & I & Kyllä \\
\hline Nasser & 32 & mies & Irak & 3 & $\begin{array}{l}\text { arabia, englanti, } \\
\text { suomi }\end{array}$ & 2 & $\mathrm{Ei}$ \\
\hline Nema & 36 & nainen & Irak & 10 & $\begin{array}{l}\text { arabia, suomi, } \\
\text { englanti }\end{array}$ & 4 & $\mathrm{Ei}$ \\
\hline Fayza & 53 & nainen & Irak & 10 & $\begin{array}{l}\text { arabia, englanti, } \\
\text { suomi }\end{array}$ & 1 & Kyllä \\
\hline Haris & 25 & mies & $\begin{array}{l}\text { Irak } \\
\text { (Kurdistan) }\end{array}$ & 9 & $\begin{array}{l}\text { kurdi, arabia, } \\
\text { turkki, suomi }\end{array}$ & 3 & $\mathrm{Ei}$ \\
\hline Salman & 40 & mies & Marokko & 4 & $\begin{array}{l}\text { arabia, espanja, } \\
\text { suomi }\end{array}$ & 1 & Kyllä \\
\hline Leyla & 28 & nainen & Palestina & 10 & arabia & I & Kyllä \\
\hline Nafisa & 36 & nainen & Somalia & 18 & somali, suomi & 4 & $\mathrm{Ei}$ \\
\hline Falis & 30 & nainen & Somalia & 7 & $\begin{array}{l}\text { somali, englanti, } \\
\text { suomi }\end{array}$ & 3 & $\mathrm{Ei}$ \\
\hline Zoya & 28 & nainen & Somalia & 3 & somali, suomi & I & Kyllä \\
\hline Fathia & 65 & nainen & Somalia & 8 & somali, suomi & 2 & Kyllä \\
\hline Barsanji & 45 & mies & Somalia & 3 & $\begin{array}{l}\text { somali, englanti, } \\
\text { suomi }\end{array}$ & I & Kyllä \\
\hline Hafida & 42 & nainen & Somalia & 3 & $\begin{array}{l}\text { somali, englanti, } \\
\text { suomi }\end{array}$ & I & Kyllä \\
\hline Hawa & 34 & nainen & Somalia & 20 & $\begin{array}{l}\text { somali, suomi, } \\
\text { englanti }\end{array}$ & 5 & $\mathrm{Ei}$ \\
\hline
\end{tabular}

* kenenkään suomen kielen taito ei ollut 0 , koska kaikki olivat jo opiskelleet hieman suomea. 
muodostui haastattelukysymysten avustamana haastateltavien luomia narraatioita eli kertomuksia heidän kokemuksistaan kaupunkiympäristössä liikkumisesta ja kaupunkiympäristön kokemisesta sekä kielimaiseman ja kielitaidon vaikutuksesta liikkuvuuteen ja palveluiden käyttöön.

Haastattelut nauhoitettiin haastateltavan suostumuksella, litteroitiin ja analysoitiin. Haastatteluaineistoa käsiteltiin diskursiivisen teemoittelun avulla. Muodostuneesta aineistosta haettiin tietoja muun muassa suunnistamisen vaikeuksista ja navigoinnin strategioista. Narraatioista haettiin lopulta kaupunkitilalle annettuja merkityksiä ja kokemuksia liikkumisesta vieraassa kieliympäristössä sekä toisaalta myös ratkaisuja navigoinnin helpottamiseksi.

\section{Tulokset}

\section{Kielitaidon vaikutus liikkumiseen ja toimimiseen uudessa elinympäristössä}

Haastateltavilta kysyttiin, millaisia vaikeuksia heikko kielitaito on heille aiheuttanut heidän liikkuessaan ja toimiessaan kaupunkiympäristössä. Monet haastateltavista ovat usein eksyneet vieraassa kaupunkiympäristössä, kun karttojen, osoitteiden ja katukylttien lukeminen on ollut heille hankalaa täydellisen lukutaidottomuuden tai vieraan kielen takia. Eksyminen voi olla väärään suuntaan kulkemista tai väärän joukkoliikennevälineen valitsemista:

Haris, mies 25-v.: Vain koulu ja kotona, ei muita paik.kaan minä lähteä. Koska joskus väärin minä lähden, suuntaan.

Hafida, nainen 42-v.: Joskus menen kaukojunaan, vaikea halusin lähijunaan. Eksymistä tapabtuu usein, kun ei tiedä. Kerran oli vaikeaa, kun olin eksynyt 100 kilometrin päähän. Oli haastattelu maahanmuuttovirastolla ja oli kotimatkalla mennyt pysäkeki obi. Jäin asemalle odottamaan ja tuttu benkilö tuli hakemaan.

Vieraan kielen takia haastateltavat eivät ole voineet tehokkaasti hyödyntää muilta ihmisiltä saatuja reitti- tai toimintaohjeita tai he eivät ole ymmärtäneet viitoituksia esimerkiksi joukkoliikenneasemilla. Tämän takia liikkuminen tuttujen alueiden ulkopuolella on hankalaa. Suomen, ruotsin tai englannin kieltä heikosti osaavien strategiana onkin pyytää tutuilta neuvoa uusiin paikkoihin mennessään. Reittiohjeet kirjoitetaan paperille tai, jos henkilö on luku- tai kirjoitustaidoton, reitin varrelta tallennetaan mieleen keskeisiä maamerkkejä. Valokuviakin käytetään hyödyksi reitin tunnistamiseksi. Jos suomen kielen taito on jo hieman kehittynyt, ovat he uskaltaneet pyytää myös tuntemattomilta reittiohjeita. Useat haastateltavat mainitsivat reittiohjeiden saamisen vaikeuden johtuvan yhteisen kielen puuttumisen lisäksi myös ihmisten ennakkoluuloista, jotka kohdistuvat varsinkin ulkomaalaisiin miehiin. Tämä asia tuli monien haastateltujen miesten vastauksista esille. Vastaantulevat ihmiset eivät joko ole ymmärtäneet, mitä heiltä kysytään, tai he ovat suoraan torjuneet avunpyynnöt. Haastatelluilla naisilla ei sen sijaan ole ollut tällaisia kokemuksia. He jopa mainitsivat, että tuntemattomat ihmiset ovat hyvin auttavaisia ja sydämellisiä.

Barsanji, mies 45-v.: Silloin, kun olen erehtynyt paikasta ja olen kysynyt vierailta, nïn be ovat pyytäneet ottamaan ybteyttä tuttuun, ja jotkut ovat vain sanoneet, etteivät ymmärrä.

Nasser, mies 32-v.: Kun minun pitää mennä johonkin paikekaan, nïn kysyn ihmisiltä. He vastaavat minulle suomeksi, enkä ymmärrä mitään. Minä kysyn englanniksi ja he vastaavat suomeksi, ja pyydän beitä puhumaan englanniksi, mutta vastaus on vain suomeksi, tai joskus he eivät pubu minulle ollenkaan. Minulla on hieman helpompaa, koska osaan englantia, mutta minun ystäväni pubuvat vain arabiaa, be yrittävät puhua myös englantia, mutta osaavat vain vähän. Heillä on todella vaikeaa.

Falis, nainen 30-v.: Tulin Suomeen ja ei ollut opetettu kieltä ollenkaan ja minut lähetettiin harjoitteluun, ei ollut koskaan kielikursseilla. Minulle annettiin kartta ja lappu, jossa luki osoite ja mihin aikaan pitää olla siellä. Ei osaa kieli ei kukaan auttamassa. Minulla oli byvä englannin kieli. Olin kysynyt joltakin afrikkalaiselta [vastaantulijalta], että voisitko auttaa, mä tarvitsen löytää tämä osoite ja sanoin en osaa 
suomea. Ja hän kysyi joltakin suomalaiselta ja hän kertoi, mikä bussi menee sinne ja mä menin bussiin ja bussikuski auttaa minua englanniksi. Sen jälkeen mä löysin.

Monet haastatelluista mainitsivat, että julkisen liikenteen käyttö on Helsingissä helppoa, ja se on auttanut heitä löytämään myös tuntemattomiin paikkoihin. Julkisen liikenteen reittiverkosto on heidän mielestään kattava ja uuteen paikkaan on helppo löytää, jos kohde on pysäkin tai aseman lähellä tai jos reitti on ennestään tuttu. Kaukana pysäkiltä tai asemalta olleen kohteen löytäminen on kuitenkin ollut heidän mielestään vaikeaa, sillä tällöin on usein joutunut pyytämään vastaantulevilta neuvoja, mikä on osoittautunut vaikeaksi, jos yhteistä kieltä ei ole tai ei ole ollut mahdollista käyttää esimerkiksi jotain karttasovellusta. Haastateltujen mukaan liikkumisen ja toimimisen mahdollistaminen vieraassa kaupunkiympäristössä onnistuu myös ilman kielitaitoa, jos henkilöllä on tarpeeksi tietoa löytää oikea paikka ja taitoa käyttää esimerkiksi jotakin karttasovellusta.

Salman, mies 40-v.: Minulle on todella hankalaa mennä unsiin paikekoibin. Liikekuminen onnistuu tutuilla paikoilla, tai jos joku tuttu on vastassa metroasemalla. Jos minun pitäisi mennä aseman alueelta kauemmaksi, nïn en pärjää ilman opastusta. Olen tottunut liikekumaan julkisilla, mutta jos pitäisi lähteä kävelemään, nïn en löydä. En osaa englantia ja osaan kirjoittaa vain arabian kirjaimilla. [...] Jos joku lähettää minulle osoitteen, nïn minun pitää tallentaa se ja etsiä osoite Google Mapsilla. Minulle pitää näyttää paikek ja reitti kunnolla.

Uuteen paikkaan löytäminen on myös aikaa vievä ja pitkä prosessi. Haastateltavat kertoivat valmistautuvansa tuntemattomaan paikkaan menemiseen ottamalla paikasta selvää sekä selvittämällä tutuilta tai mahdollisesti karttasovelluksen avulla, miten paikkaan mennään ja kuinka kauan sinne kestää matkustaa. Perusteellisesta valmistautumisesta huolimatta joillekin haastatelluista on kuitenkin tullut hankaluuksia löytää oikea paikka kohteeseen saapumisen jälkeen. Joskus heille on jopa käynyt niin, ettei kohde ole löytynyt ja he ovat etsimisestä väsyneenä tai tapaamisesta myöhästyneenä palanneet takaisin kotiin.

Zoya, nainen 28-v.: Kerran minun lapsella oli neuvola-aika, ja se oli Myllypurossa aikaisemmin, mutta ne [neuvola] munttivat Itäkeskukseen. En tiennyt missä paikassa, en voinut kysyä suomalaiselta, koska ei ollut rïttävä kielitaito, tai en osannut selittää. Ja näin somalialaisen ja kysyin, mutta hekään eivät tienneet, heillä ei varmaan ollut lapsia. Kävelin edestakaisin, sïnä meni tosi kauan. En löytänyt paikekaa ja sitten menin takaisin kotiin. Väsyin ja menin kotiin. Sïnä oli paljon rakennuksia yhdessä paikassa, samannäköisiä kaikeki, nïn oli vaikea tunnistaa oikeaa paikekaa.

Barsanji, mies 45-v.: Minut sïrrettïn Vantaalle ja minun piti mennä sosiaalitoimistoon. Ensimmäisellä kerralla minut vietiin autolla ja toisella kerralla minun piti mennä itse ja kesti todella kanan löytää paikekaan. En ollut vielä oppinut teiden nimiä nün oli hankalaa. On paljon ongelmaa, kun ibminen on unsi maassa. Ei ole helppoa oppia. Paikeojen oppiminen kestää kanan.

Haastatellut tarvitsevat eniten apua suomen kielen oppimisen ja erilaisten asioiden hoitamisen kanssa. Ongelmia esiintyy varsinkin paperiasioiden kanssa. Haastatellut henkilöt haluaisivat pystyä toimimaan arjessa itsenäisesti, mutta heikko valtakielen osaaminen asettaa tälle esteitä. Itsenäisesti toimiminen voi olla arkipäiväisten asioiden hoitamista, kuten Kelassa tai lääkärissä asiointia, tai erilaisiin paikkoihin matkustamista.

Leyla, nainen 28-v.: Mä kävin pankissa, mä halusin tehdä verkkopankkitunnukset, mutta en osannut pubua. Vaikeka otin sen vuoronumeron, mut sit sen jälkeen heitin sen pois ja menin sieltä pois, koska en osannut pubua.

Fayza, nainen 53-v.: Haluan oppia, miten mennä Espooseen, Vantaaseen. [...] En pubu, tämä vaikea. Koska ei pubu niin on helpompi olla kotona. 
Salman, mies 40-v.: Vaimoni hoitaa kaikki asiat puolestani, hän auttaa varaamaan ja opastamaan uusiin paikeoihin. Haluaisin kuitenkin osata itse.

\section{Kielimaiseman vaikutus kohdemaan kieltä heikosti osaavien maahanmuuttajien liikkuvuuteen}

Vieraaseen kielimaisemaan saapuminen on tuntunut hastateltavista uudelta ja oudolta. He kertoivat, etteivät he olleet omissa maissaan tottuneet näkemään niin paljon kirjoitusta kaupunkiympäristöissä. Monet haastateltavat olivat Suomeen tullessaan tai vielä haastattelun aikana luku- ja kirjoitustaidottomia, joten varsinkin heistä runsas tekstien määrä kaupunkiympäristössä tuntui oudolta.

Zoya, nainen 28-1.: Se oli untta ja uusia, kaikkeea. Meidän maassa ei ollut tollanen. Ei ymmärtänyt, ei mitään, mutta sen ymmärtää, että jotain osoittaa, että mene tonne tai käänny tonne, se on vaikea.

Rashid, mies 23-v.: Tuli tosi paljon ongelmia, esimerkiksi, kun olimme kaupungilla, emmekä tienneet mitä siinä lukee, nämä kyltit, ja missä kaupat ovat. [...] Aina piti soittaa objaajille tai joskus ottaa objaajat mukaan ostoksille. Eli tosi vaikea oli.

Vieraaseen kielimaisemaan saapuminen on aiheuttanut myös osalle haastatelluista pelon tunteita. Nämä tunteet kumpuavat eksymisen pelosta heikon valtakielen osaamisen seurauksena. Kun heikosti kohdemaan kieltä osaava maahanmuuttaja ei pysty käyttämään navigoinnin apuna karttoja tai tuntemattomien ihmisten reittiohjeita, voi eksymistä tapahtua usein. Eksyminen vieraassa ympäristössä luo turvattomuuden tunteita sekä levottomuutta.

Barsanji, mies 45-1:: Tuntui siltä, että kun olet unsi ja on kirjoitettu eri kielellä ja tulee pelko ja yrität oppia untta kieltä. [Se pelko tulee] kielitaidottomundesta. Että jos kuljet jossakin ulkona ja siitä kielitaidottomundesta tulee pelko. Että eksyt tai menet väärään paikkaan. Tuntun vielä vähän pelkoa ja jännitystä, että ekssy tai myöhästyy, että ei löydä paikkaa ja eksyy. Avain on se, että on ybteisymmärrys, kieli ja että ibmiset toimivat toisten kanssa.

Nasser, mies 32-1.: Kun en tiedä miten jonnekin mennään, se saa oloni vaikeaksi. Olen ollut täällä nyt jo kauan ja tunnen kaupungin ja osaan englantia, mutta on niin monia benkilöitä, jotka eivät tiedä, miten jonnekin mennään. He tietävät vain Kampin, Itäkeskuksen ja rautatieaseman. He kysyvät minulta, kavereilta, ja tuntemattomilta. He eivät osaa käyttää Googlea tai karttoja, se on ongelma. Jos he osaisivat vähän englantia, niin se auttaisi. Joten kielitaito auttaisi.

Eksymisen pelko on useille haastatelluille johtanut myös siihen, että he välttävät uusiin paikkoihin menemistä. He kuitenkin haluaisivat käydä uusissa paikoissa ja käyttää palveluita enemmän, mutta tiedon etsiminen ja liikkuminen uusiin paikkoihin on heikon kielitaidon takia hankalaa.

Leyla, nainen 28-v.: En käy ulkopuolisissa paikoissa, pelkeästään Vuosaaressa liikun, tunnen tämän paikan byvin ja käyn lenkillä. Itäkeskukseen osaan tulla ja mennä takaisin, mutta en osaa mibinkään munalle mennä. [...] Minä en osaa mennä uusiin paikkoibin ja mä pelkään, että eksyn tai en löydä takaisin kotiin tai en osaa mennä sinne. Kun menen unteen paikkaan, nïn olen silloin iloinen, abaa olen menossa katsomaan unteen paikekaan. Se on viihtyvää ja parempi mulle, että mä opin näistä asioista.

Nafisa, nainen 36-v:: Ei ole helppoa läbteä [unteen paikkaan]. Tulee vähän pelkotunnetta. Suomessa on turvallista, mutta pelkoa siitä, että eksytkö, ehditkë oikeaan aikaan, sellainen ei ole rentoa.

Salman, mies 40-1.: Menen harvoin tuntemattomïn paikkoibin. En halua eksyä. Jos minun pitää mennä jonnekin tuntemattomaan paikkaan nïn voi olla bankalaa. Mutta yleensä kuljen tutuissa paikoissa.

Nasser, mies 42-v: Ei ole helppoa [mennä unsiin paikkoibin]. Se on todella vaikeaa. Minun pitää pyytää neuvoja. Ennen oli todella vaikeaa. Mutta nykyään, jos minulla on osoite, voin löytää sinne 
[kearttasovelluksen avulla]. Jos minulla ei ole osoitetta, minun pitää kysyä. Mutta jos se ei ole tärkeää, nïn en mene.

Nema, nainen 36-v.: Minä haluan mennä uusi paik.ka. Ei aina jaksa mennä sama paik.ka, minä haluan uusi paikeka. Olen asunut 10 vuotta [Suomessa], vain tiedän mitä on lähellä, vain tiedän mikë on Itis ja tämä paikeka [Vuosaari]. Minä haluan mennä Helsinki [keskusta], ravintoloita, Kamppi... Jos ei oppii, ei mene.

Jotkut haastatellut maahanmuuttajat ovat osanneet Suomeen tullessaan jonkin verran englantia. Tämä on auttanut heitä liikkumaan suomalaisessa kielimaisemassa. He mainitsivat myös, että omalla aktiivisuudella on merkitystä ja vain liikkumalla kaupungissa voi saada lisää kokemusta ja itsevarmuutta toimia kaupunkiympäristössä. Tällöin uusiin paikkoihin löytäminen on heikosta valtakielen osaamisesta huolimatta mahdollista.

Hafida, nainen 42-v.: Minulla ei ole ongelmia kaupungissa liikkeumisessa. Pitää tutustua kaupunkiin nïn sitten voi liikkeua helpommin. Osaan pubua englantia ja sen avulla pärjä̈n.

Asim, mies 42-v.: Olen tyytyväinen, ei ole mitään ongelmia. Junat ovat aina ajallaan ja on siistiä ja kaupungissa on turvallista. Kielitaidottomundesta ei minulla ole ollut mitään ongelmia, olen tottunut liikekumaan. Kokemuksen kautta tulee enemmän itsevarmuntta. Jos en tunne paikeaa, nïn katson kartasta.

Kartan käyttäminen ei monille haastatelluille ollut ennestään tuttua. He kertoivat olevansa ennemminkin tottuneita pyytämään tutuilta tai vierailta ihmisiltä neuvoja paikkaan löytämisessä, sillä se on heidän kulttuurissaan tavallisempaa kuin itsenäisesti liikkuminen kartan avulla. Erään haastattelun aikana haastattelija sai jopa opettaa haastateltaville karttasovelluksen ja Helsingin Seudun Liikenteen reittisovelluksen käyttöä. Tämä lyhyt opetustuokio kasvatti jo haastateltavien itsevarmuutta liikkua kaupunkiympäristössä itsenäisesti ja hakea tietoa esimerkiksi julkisen liikenteen linjoista. Osalle haastateltavista GPS paikannukseen perustuvien karttasovellusten käyttäminen oli kuitenkin jo tuttua ja he mainitsivat GPS:n auttavan heitä löytämään ennestään tuntemattomiin paikkoihin. Reittiopasta käyttävät mainitsivat, että reittioppaan ja auttavaisten bussikuskien avulla uuteen paikkaan on helppo löytää. Apua ennestään tuntemattomaan paikkaan löytämisessä antaa myös joukkoliikennevälineiden infotauluissa näkyvät seuraavien pysäkkien nimet, joita voi matkan varrella seurata ja verrata omiin muistiinpanoihin tai toisenlaisiin saatuihin ohjeisiin.

\section{Pohdinta ja johtopäätökset}

\section{Fyysisen ympäristön vaikutus vieraassa kielimaisemassa liikkuvan henkilön tilallisuuden kokemiseen}

Ymmärtääksemme, miten heikosti kohdemaan kieltä osaava maahanmuuttaja kokee ympäröivän elinympäristönsä, oli tässä tutkimuksessa ensin ymmärrettävä, miten kaupunkitila määritellään. Tilan määrittelyssä käytettiin Lefebvren (1991) määritelmää tilasta, jossa tila jaetaan fyysiseen, sosiaaliseen ja relationaaliseen tilaan. Tilan fyysinen ulottuvuus eli tila todellisuuden representaationa viittaa suunniteltuun tilaan. Heikosti valtakieltä osaava maahanmuuttaja näkee kaupunkiympäristössä paljon vierasta kieltä ja tuntemattomia symboleita. Monet kaupunkialueet ovat heidän mielestään myös samankaltaisia, koska alueilta puuttuu yksilöivä arkkitehtuuri. Tällaisessa fyysisessä tilassa liikkuminen voi olla vaikeaa heikosti valtakieltä osaavalle maahanmuuttajalle vieraasta kielimaisemasta ja homogeenisestä kaupunkisuunnittelusta johtuen.

Sosiaalinen ja relationaalinen tila näyttäytyy spatiaalisten käytäntöjen areenana eli havaittuna ja elettynä tilana sekä representaatioiden näyttämönä eli kokemuksina eletystä ja ymmärretystä tilasta (Lefebvre 1991; Johnson \& Miles 2014). Heikosti ympäristön kieltä osaava mahanmuuttaja kokee kaupunkiympäristössä havaitsemansa tuntemattoman kirjoitetun ja 
puhutun kielen vieraana ja outona. Vieraan kielen takia hän ei pysty toimimaan esimerkiksi katukylteissä, opasteissa ja kieltotauluissa esitellyllä tavalla. Hän havaitsee muiden ihmisten toimivan tässä samaisessa ympäristössä luontevasti, muttei koe itse pystyvänsä samaan. Maahanmuuttaja ei siis kykene toimimaan spatiaalisten käytäntöjen mukaisesti, mikä voi tuntua hänestä ahdistavalta, turhauttavalta, pelottavalta ja epämukavalta. Tätä kielimuurin aiheuttamaa estettä valtakieltä heikosti osaava voi kiertää esimerkiksi seuraamalla muiden samassa tilassa liikkuvien käytöstä tai opettelemalla käyttämään karttasovelluksia ja GPS-toimintoa, joiden avulla hän voi kielitaidottomanakin liikkua kaupunkitilassa.

Kielimaiseman kautta kaupunkitila muodostuu sosiaaliseksi tilaksi. Suomalaisessa kaupunkiympäristössä sosiaalinen tila on kielimaisemaltaan suomen- ja ruotsinkielistä. Henkilön, joka ei näitä kyseisiä kieliä osaa, voi olla vaikea liittyä tähän sosiaaliseen tilaan, joten he saattavat jäädä sosiaalisen yhteisön ulkopuolelle (esim. Johnson \& Miles 2014). Tällöin sosiaalinen oikeudenmukaisuuskaan ei toteudu. Fyysisen tilan rakentamisen yhteydessä tehtyjen valintojen takia heikosti kieltä osaavan on mahdotonta toimia itsenäisesti kaupunkitilassa, joka rakentuu vieraasta kielimaisemasta. Sosiaaliseen tilaan kontaktia ottaessaan osa maahanmuuttajista saatetaan torjuta, koska he eivät esimerkiksi osaa kieltä (esim. Nagel \& Staeheli 2004; Johnson \& Miles 2014). Heitä ei siis oteta osaksi sosiaalista tilaa. Muokkaamalla muun muassa kaupunkiympäristöjen kielimaisemaa voidaan tähän yhteen sosiaalisen oikeudenmukaisuuden epäkohtaan kuitenkin puuttua.

\section{Vieraassa kielimaisemassa ja kaupunkiympäristössä liikkumista auttavat hyvät navigoinnin strategiat}

Erilaisista kieliympäristöistä Suomeen saapuneet maahanmuuttajat kokevat ympäröivän kaupunkitilan outona ja tuntemattomana vieraan kielimaiseman ja kohdemaan kielen osaamattomuuden takia. Tämä vieras kielimaisema aiheuttaa heille hankaluuksia liikkua ja toimia kaupunkiympäristössä. Haastatteluista kävi ilmi, että heikosti valtakieltä osaavat maahanmuuttajat ovat kohdanneet vaikeuksia löytää tuntemattomiin paikkoihin. Aikaisemmat epäonnistumisen kokemukset ovat lisäksi johtaneet turhautumiseen ja ahdistumiseen, mikä muutamissa tapauksissa on myös johtanut eristäytymiseen. Haastatteluiden kautta saadut tulokset ovat linjassa aiheesta tehtyjen aiempien tutkimusten kanssa (esim. Secor 2004; Hund \& Minarik 2006; Chang 2013, 2015; Yu 2016). Pelko aiempien negatiivisten kokemusten toistumisesta voi johtaa heikosti valtakieltä osaavan henkilön sulkeutumiseen kotiinsa tai liikkumisen rajoittumiseen suppean arkiympäristön sisäpuolelle.

Heikon kielitaidon takia maahanmuuttajat ovat kokeneet hankalaksi löytää oikeaa reittiä tai joukkoliikennelinjaa haluttuun päämäärään. Reittiohjeita on ollut haastateltavien mukaan hankala pyytää vastaantulevilta yhteisen kielen puuttumisen takia. Kartoista ei ole ollut osalle haastateltavista apua, sillä heille kartan käyttäminen on ollut ennestään vierasta tai kartan käyttäminen on koettu vaikeaksi sen runsaan tekstimäärän takia. Halutun päämäärän löytyminen on tuntunut haastateltavista aikaa vievältä ja raskaalta prosessilta. Joskus kohde on jäänyt löytymättä tai sovitusta tapaamisesta on myöhästytty. Halutun kohteen löytyminen on ollut vaikeaa, sillä sitä ei ole osattu tunnistaa ympäröivistä rakennuksista eikä henkilön ole ollut mahdollista ymmärtää esimerkiksi rakennusten ovissa olevaa tekstiä. Useat haastatelluista mainitsivatkin yllä esitettyjen asioiden johtaneen eksymisen pelkoon vieraassa kaupunkiympäristössä liikkuessaan, mikä osaltaan on vähentänyt heidän halukkuuttaan liikkua tutun arkiympäristön ulkopuolella tai käyttää uusia palveluita. Uuteen elinympäristöön muuttaneilla maahanmuuttajilla on kuitenkin suuri halu laajentaa arkiympäristöään, vierailla uusissa paikoissa ja käyttää erilaisia palveluita.

Haastatelluilla maahanmuuttajilla on useita hyviä navigointia helpottavia strategioita, joiden avulla he pystyvät ohittamaan kielimuurin vaikutuksia kaupunkiympäristössä liikkuessaan. Pääasiallisena liikkumisen strategiana heikosti valtakieltä osaavat maahanmuuttajat käyttävät tutuilta ja mahdollisuuksien mukaan myös tuntemattomilta ihmisiltä tulevia reittiohjeita. Tämä on luonnollinen tapa toimia, sillä monissa kulttuureissa on tapana ennemminkin ottaa ihmiskontaktia kuin toimia itsenäisesti. Lisäksi esimerkiksi karttojen käyttäminen voi lukutaidon 
puuttumisen takia olla mahdotonta. Myös tällöin on reittiohjeiden kysyminen luonnollisempi tapa selvitä tilanteesta.

Usein kohdemaan kieltä heikosti osaava maahanmuuttaja kirjoittaa kohteen osoitteen paperille ja näyttää sitä vastaantulijalle tai bussikuskille, jotka osoittavat, mihin suuntaan kysyjän tulisi kulkea tai millä pysäkillä hänen pitää jäädä pois. Joukkoliikennevälineissä orientoitumista helpottaa se, että liikennevälineen näytöllä lukee seuraavien pysäkkien nimet. Näitä nimiä maahanmuuttaja vertaa saamaansa reittiohjeisiin ja hän voi nimien kirjaimia vertailemalla seurata etenemistään reitin varrella. Näin hän saa tietää, millä pysäkillä hänen tulisi jäädä pois.

Yleinen navigoinnin strategia oli myös se, että joku tuttu on vienyt henkilön kohteeseen, minkä jälkeen reitti on pitänyt muistaa ulkoa seuraavalla kerralla. Tällöin liikkumisen yhteydessä on kiinnitetty huomiota ensisijaisesti maamerkkeihin. Maamerkkien avulla henkilö muistaa joko olleensa kyseisessä paikassa aikaisemmin ja pystyy maamerkin avulla orientoitumaan kohti oikeaa suuntaa tai hän pystyy suunnistamaan ennestään tuntemattomassa kaupunkiympäristössä suullisten reittiohjeiden ja maamerkkien avulla (esim. Allen 1999; Chang 2015; Parente 2016). Karttasovelluksista, kuten Google Maps tai HSL Reittiopas, on paljon apua henkilöille, jotka osaavat näitä sovelluksia käyttää.

Heikon kielitaidon ja vieraan kielimaiseman lisäksi myös aiemmat kokemukset vaikuttavat halukkuuteen liikkua kaupunkiympäristössä. Varsinkin miesten vastauksista kävi ilmi valtaväestön ennakkoluuloisuus ja rasistinen suhtautuminen maahanmuuttajia kohtaan, mikä on vähentänyt heidän halukkuuttaan liikkua julkisilla paikoilla. Samankaltaisia tuloksia sai myös Nagel ja Staeheli tutkimuksessaan (2004). Myös yksinäisyys voi alhaisen liikkuvuuden yksi osatekijä. Heillä ei ole tukiverkostoa, jolta pyytää apua esimerkiksi heidän eksyessään vieraassa kaupunkiympäristössä. Heikko valtakielen taito lisää vielä hankaluutta kommunikoida tuntemattomien ihmisten kanssa. Yksinäisyyttä voi vähentää sosiaalisten palveluiden avulla, mutta jo kotoutumisprosessissa pitäisi ottaa huomioon yksinäisten henkilöiden mahdollisuudet liikkua kaupunkiympäristössä ja käyttää palveluita. Tämän voisi esimerkiksi tehdä opettamalla heille, miten karttasovelluksia käytetään ja miten haetaan tietoa joukkoliikenneyhteyksistä.

\section{Kielellisesti esteetön kaupunkiympäristö}

Kielellisen saavutettavuuden parantaminen edistää julkisten resurssien tasa-arvoista jakautumista ja sitä kautta myös sosiaalisen oikeudenmukaisuuden toteutumista yhteiskunnassa. Pitäisi siis varmistaa se, että myös heikosti valtakieltä osaavien maahanmuuttajien olisi mahdollista integroitua sosiaaliseen tilaan. Tämän tutkimuksen aikana selvisi sekä kirjallisuuden että empiirisen osion haastatteluiden kautta, että tämä voidaan saavuttaa esimerkiksi

1) suunnittelemalla fyysistä tilaa siten, että maamerkkien muodostuminen mahdollistuu,

2) muuttamalla kielimaisemaa esteettömämmäksi yleistajuista symbolikieltä lisäämällä,

3) kiertämällä fyysisen tilan ja kielitaidottomuuden aiheuttamat esteet karttasovellusten käyttöä opettamalla,

4) luomalla heikosti valtakieltä osaaville soveltuvia palveluita, kuten kielellisesti esteettömiä karttasovelluksia, tai tarjoamalla peruspalveluita vähintään suurilla vähemmistökielillä, sekä

5) valistamalla valtaväestöä maahanmuuttajien integroitumisen tärkeydestä.

Hyvin suunniteltu kaupunkiympäristö on yksi niistä tekijöistä, joiden avulla voi vieraan kielimaiseman aiheuttamia liikkuvuuden esteitä vähentää (mm. Johnson \& Miles 2014). Koska kaupunkiympäristöjen muotoutuminen alkaa kaavoituksesta ja muusta tarkemmasta suunnittelusta, olisikin jo näissä vaiheissa hyvä miettiä syntyvää kokonaisuutta saavutettavuuden ja kielellisen esteettömyyden näkökulmasta. Hyvin tehdyt suunnitelmat luovat hedelmällisen pohjan muun muassa kielellisesti saavutettavan ympäristön rakentamiselle. Monipuolisiksi ja persoonallisiksi suunnitellut kaupunkiympäristöt auttavat oman sijaintinsa tunnistamista, kun liikkuessa muistiin on piirtynyt kuva eri alueille ominaisista rakennuksista tai kaupunkirakenteesta (mm. Hund \& Minarik 2006). Haastatteluiden aikana tuotiin esille, että homogeeninen kaupunkiympäristö aiheuttaa yhdessä heikon kielitaidon kanssa hankaluuksia 
löytää haluttuun kohteeseen (Haastattelu: Zoya, 16). Ympäristöstään erottuvat eriväriset ja -muotoiset rakennukset jäävät helposti mieleen ja niistä muodostuu maamerkkejä ihmisen kognitiiviseen karttaan, jolloin niiden avulla on helppo orientoitua tilassa (esim. Allen 1999; Wiener ym. 2009; Parente 2016; Haastattelu: Nasser). Maamerkkien avulla kaupunkitilassa on helpompi suunnistaa, vaikkei välttämättä ympäristön kieltä osaisikaan.

Olemassa olevien maamerkkien tunnistaminen ja uusien maamerkkien rakentaminen avaa mahdollisuuksia luoda uudenlaisia navigointipalveluita laajemmalle kohderyhmälle. Nykypäivän karttasovellukset mahdollistavat jo 3D kuvan esittämisen. Tätä toiminnallisuutta voisi käyttää hyödyksi ja luoda heikosti ympäristön kieltä osaaville navigointisovelluksen, joka toimisi pääasiallisesti maamerkkien ja symboleiden kautta. Tällaista palvelua monet haastateltavat toivoivat ja asiaa on suositeltu myös aiemmissa tutkimuksissa (esim. Richter \& Winter 2014; Chang 2015; Vaittinen \& McGookin 2016). Chang (2015) sekä Vaittinen ja McGookin (2016) ovat lisäksi tuoneet esille, että symbolikieltä voisi lisätä kaupunkiympäristössä yleisestikin. Nykyisellään kaupunkiympäristössä on viitoituksia, joissa osoitetaan esimerkiksi terveyskeskuksen, kirjaston tai rautatieaseman sijainti kirjoituksena, mutta nämä viitoitukset eivät palvele heikosti kieltä osaavia henkilöitä. Sama tieto tulisi suuremmalle kohderyhmälle saavutettavaksi, jos kirjalliset viitoitukset korvattaisiin tai täydennettäisiin esimerkiksi yleistajuisilla symboleilla. Symbolien ongelmana on kuitenkin se, että eri kulttuureissa on totuttu käyttämään hieman erilaisia symboleita, eikä virallisia yleismaisia symboleita ole vielä kehitetty. Kuitenkin kohteista, kuten terveyskeskus ja rautatieasema, olisi mahdollista käyttää melko yleistajuisia symboleita. Tällaisia symboleita voisikin kaupunkiympäristöön lisätä, jotta heikosti ympäristön kieltä osaavat löytäisivät helpommin keskeisiin palveluihin.

Uusiin paikkoihin olisi haastateltujen henkilöiden mielestä helpompi löytää, jos esimerkiksi viranomaisilta tulleissa kirjeissä olisi maininta, mikä joukkoliikennelinja kohteeseen tulisi valita vaikkapa monien maahanmuuttajien tuntemalta Helsingin päärautatieasemalta. Lisäksi paikan löytämistä helpottaisi, jos kirjeisiin lisättäisiin kuva kohteessa olevan rakennuksen ulkonäöstä tai jos kirjeessä olisi maininta kohteen läheisyydessä sijaitsevasta tunnetusta tai helposti tunnistettavasta maamerkistä (haastattelut: Nasser, Zoya, Rashid). Tämän voisi tehdä liittämällä paperiseen tai elektroniseen viestiin linkin tai QR-koodin, jonka kautta avautuisi esimerkiksi kuva kohteesta tai reittiohjeet kohteeseen jostakin ennestään tutusta paikasta. Haastateltavat mainitsivat myös, että useissa joukkoliikennevälineissä käytössä olevat infotaulut ja ääni-ilmoitukset helpottavat reitin seuraamista esimerkiksi omista muistiinpanoista. Kirjallista ja sanallista informaatiota seuraavasta pysäkistä toivottiinkin käytettävän useammissa joukkoliikennevälineissä. Nykyisin esimerkiksi pääkaupunkiseudulla ei kaikissa busseissa ole infotauluja käytössä.

Haastatteluissa mainittiin ihmisoppaiden lisäämisen helpottavan kaupunkiympäristössä liikkumista. Tämä ehdotus liittyy siihen, että monissa Lähi-Idän ja Afrikan kulttuureissa on totuttu pyytämään muilta ihmisiltä neuvoja sen sijaan, että tietoa etsittäisiin itsenäisesti. Luku- ja kirjoitustaidottomien on lisäksi vaikea hakea tietoa itsenäisesti kirjallisista lähteistä. Ihmisoppaat olisivat hyödyllisiä varsinkin sellaisille henkilöille, joilla ei ole mahdollisuutta pyytää neuvoja tutuilta. Helposti tunnistettavilta oppailta olisi heikosti valtakieltä osaavan mukavampaa käydä kysymässä neuvoja, kun pelko torjutuksi tulemisesta vähenee. Ihmisoppaita käytetään jo esimerkiksi Ruotsissa ja monilla lentokentillä. (Haastattelu: Hawa)

\section{Kielimaiseman vaikutus maahanmuuttajien liikkuvuuteen on tärkeä tutkimuskohde}

Kielimaiseman tutkimuksessa olisi hyödyllistä tulevaisuudessa keskittyä enemmän siihen, miten kielimaisema vaikuttaa liikkuvuuteen ja saavutettavuuteen. Nash (2016) on arvostellut katsauksessaan sitä, että kielimaiseman tutkijat ovat enimmäkseen kielitieteilijöitä ja sosiolinguisteja. Maisemantutkijoiden, maantieteilijöiden ja aluetieteilijöiden kannattaisikin jatkossa ottaa enemmän kantaa kielimaisemaan ja siihen, miten se vaikuttaa spatiaaliseen ymmärrykseen ja liikkuvuuteen. Tämä artikkelin pyrkimyksenä on ollut avata kielimaisemaan liittyvää problematiikkaa heikosti ympäristön kieltä osaavien maahanmuuttajien liikkuvuuden näkökulmasta, sekä esittää muutamia ehdotuksia siihen, miten kaupunkiympäristöstä saisi kielellisesti esteettömän. Näistä aiheista toivottavasti kirjoitetaan enemmän tulevaisuudessa. 
Kielimaisemalla on tämän tutkimuksen perusteella vaikutusta heikosti valtakieltä osaavien maahanmuuttajien liikkuvuuteen pääkaupunkiseudulla. Tulokset olivat samansuuntaiset kuin lähdekirjallisuudessa esitetyt tulokset (esim. Chang 2013; 2015; Yu 2016). Liikkuvuuden edistäminen on sosiaalisen oikeudenmukaisuuden ja julkisten resurssien tasa-arvoisen jakautumisen kannalta oleellinen tekijä. Kielimaiseman vaikutusta liikkuvuuteen ei kuitenkaan ole tutkittu vielä tarpeeksi. Tämä tutkimus on hieman raottanut aiheen merkitystä kaupunkisuunnitteluun, maahanmuuttajien kotoutumiseen ja sosiaalisen oikeudenmukaisuuden toteutumiseen, mutta aihetta olisi hyvä tutkia vielä syvemmin, kuin mitä tämän tutkimuksen puitteissa oli mahdollista. Lisäksi olisi tarpeellista tutkia kielimaiseman vaikutusta kansalaiskäsitykseen ja paikkaan kiintymiseen. Näillä teemoilla on merkitystä maahanmuuttajien mielenterveyteen sekä viihtyvyyteen uudessa elinympäristössä ja kotimaassa.

\section{Lähteet}

Allen, G. L. (1999) Cognitive abilities in the service of wayfinding: a functional approach. The Professional Geographer, 51(4) 555-561. https://doi.org/10.1111/0033-0124.00192

Ben-Rafael, E., Shohamy, E., Amara, M. H. \& Trumper-Hecht, N. (2006) Linguistic landscape as symbolic construction of the public space: the case of Israel. Julkaisussa Gorter, D. (toim.) (2006). International Journal of Multilingualism 3(1) 7-30. https://doi.org/10.1080/14790710608668383

Chang, H.-H. (2013) Wayfinding strategies and tourist anxiety in unfamiliar destinations. Tourism Geographies 15(3) 529-550. https://doi.org/10.1080/14616688.2012.726270

Chang, H.-H. (2015) Which one helps tourists the most? Perspectives on international tourists using different navigation aids. Tourism Geographies 17(3) 350-369. https://doi.org/10.1080/14616688.2015.1016099

Denis, M., Pazzaglia, F., Cornoldi, C. \& Bertolo, L. (1999) Spatial discourse and navigation: an analysis of route directions in the City of Venice. Applied Cognitive Psychology 13 145-174. https://doi.org/10.1002/(SICI)10990720(199904)13:2<145::AID-ACP550>3.0.CO;2-4

Ferretti, F., Adornetti, I., Cosentino, E. \& Marini, A. (2013) Keeping the route and speaking coherently: The hidden link between spatial navigation and discourse processing. Journal of Neurolinguistics 26 327-334. http://dx.doi. org/10.1016/j.jneuroling.2012.11.001

Frankenstein, J., Brüssow, S., Ruzzoli, F. \& Hölscher, C. (2012) The language of landmarks: the role of background knowledge in indoor wayfinding. Cogn Process 13(1) S165-S170. https://doi.org/10.1007/s10339-012-0482-8

Gale, N., Golledge, R. G., Pellegrino, J. W. \& Doherty, S. (1990) The acquisition and integration of route knowledge in an unfamiliar neighborhood. Journal of Environmental Psychology 10 3-25. https://doi.org/10.1016/S02724944(05)80021-0

Geurs, K. T. \& van Wee, B. (2004) Accessibility evaluation of land-use and transport strategies: review and research directions. Journal of Transport Geography 12 127-140. https://doi.org/10.1016/j.jtrangeo.2003.10.005

Gorter, D. (2006) Introduction: the study of the linguistic landscape as a new approach to multilingualism. International Journal of Multilingualism 3(1) 1-6. https://doi.org/10.1080/14790710608668382

Harvey, D. (2003) The right to the city. International Journal of Urban and Regional Research 27(4) 939-941. https://doi. org/10.1111/j.0309-1317.2003.00492.x

Hay, R. (1998) Sense of place in developmental context. Journal of Environmental Psychology 18 5-29. https://doi. org/10.1006/jevp.1997.0060

Hölscher, C., Tenbrink, T. \& Wiener, J. M. (2011) Would you follow your own route description? Cognitive strategies in urban route planning. Cognition 121 228-247. https://doi.org/10.1016/j.cognition.2011.06.005

Hund, A. M. \&Minarik, J. L. (2006) Getting from here to there: spatial anxiety, wayfinding strategies, direction type, and wayfinding efficiency. Spatial Cognition and Computation 6(3) 179-201. https://doi.org/10.1207/ s15427633scc0603_1

Johnson, A. M. \& Miles, R. (2014) Toward more inclusive public spaces: learning from the everyday experiences of Muslim Arab women in New York City. Environment and Planning A 46 1892-1907. https://doi.org/10.1068/a46292

Kitson, A., Sproll, D. \& Riecke, B. E. (2016) Influence of ethnicity, gender and answering mode on a virtual pointto-origin task. Frontiers in Behavioral Neuroscience 10(22) 1-18. https://doi.org/10.3389/fnbeh.2016.00022

Koskela, H. (1995) Ambivalentti pelkojen kaupunki. Teoksessa Schulman, H. \& V. Kanninen (toim.), Kaupunki kobtauspaikekana 61-70. YTK:n julkaisuja C33. TKK, YTK, Espoo.

Kuisma, S. (2017) Towards a more comprehensive picture of mobility - personal preferences, resources and constraints of daily travel. Hyväksytty Pro Gradu -tutkielma, Helsingin yliopisto, geotieteiden ja maantieteen laitos. https://mycourses. aalto.fi/pluginfile.php/611519/mod_resource/content/1/Kuisma_2017_Mobility.pdf

Lefebvre, H. (1991) The production of space. Kääntänyt D. Nicholson-Smith. Blackwell, Oxford.

Levinson, S. C. (1996) Language and space. Annual Review of Anthropology 25 353-382. https://doi.org/10.1146/ annurev.anthro.25.1.353

Linderborg, L. (2008) Ikääntyneet maahanmuuttajat Suomessa. Teoksessa: Nylund, A. (toim.) Monikulttuurista byvinvointia vanbustyöhön. Turun ammattikorkeakoulun raportteja 69 24-31. http://julkaisut.turkuamk.fi/ isbn9789522160416.pdf 
Liu, R. \& Schachter, H. L. (2007) Mobility information needs on immigrants with Limited English Proficiency (LEP) in New Jersey. Journal of Immigrant \& Refugee Studies 5(2) 89-108.

https://doi.org/10.1300/J500v05n02_05

Most-Project (2008) Promoting independence in resettlement. Final publication of the Most project. Sisäasiainministeriön julkaisusarja. Edita Prima Oy, Helsinki 2008. https://www.resettlement.eu/sites/icmc/ files/MOST\%20Project_0.pdf]

Nagel, C. R. \& Staeheli, L. A. (2004) Citizenship, identity and transnational migration. Arab immigrants to the United States. Space and Polity 8(1) 3-23. https://doi.org/10.1080/13562570410001678860

Nash, J. (2016) Is linguistic landscape necessary? Landscape Research 41(3) 380-384. https://doi.org/10.1080/0142 6397.2016.1152356

Neely, B. \& Samura, M. (2011) Social geographies of race: connecting race and space. Ethnic and Racial Studies, 34(11) 1933-1952. https://doi.org/10.1080/01419870.2011.559262

Nieminen, A. (2011) Maahanmunttajien kokemuksia Suomesta: 17 maahanmunttajan kokemuksia Suomesta. Hyväksytty opinnäytetyö, Satakunnan ammattikorkeakoulu. http://www.theseus.fi/bitstream/handle/10024/33346/ nieminen_annamaria.pdf.pdf?sequence $=1$ \&isAllowed $=\mathrm{y}$

Parente, P. (2016) Moving through language: a behavioral and linquistic analysis of spatial mental model construction. Tarkastettu väitöskirja, University of Nottingham. http://eprints.nottingham.ac.uk/37620/1/Fabio\%20 Parente $\% 20-\% 20 \mathrm{PhD} \% 20$ thesis.pdf

Richter K.-F. \& Winter, S. (2014) Landmarks. GIScience for intelligent service. Springer International Publishing, Switzerland 2014.

Salmela, M. (2012) Maabanmunttajien kokemuksia sopeutumisesta suomalaiseen ybteiskuntaan. Hyväksytty Pro Gradu -tutkielma, Jyväskylän yliopisto.https://jyx.jyu.fi/dspace/bitstream/handle/123456789/40325/ URN:NBN:fi:jyu-201211143007.pdf?sequence $=1$

Secor, A. (2004) "There is an Istanbul that belongs to me": citizenship, space, and identity in the city. Annals of the Association of American Geographers 94(2) 352-368. https://doi.org/10.1111/j.1467-8306.2004.09402012.x

Sisäministeriö (2017) Maahanmuutto. Turvapaikanhakijat ja pakolaiset. Pakolainen pakenee vainoa kotimaassaan. bttp:// intermin.fi/ maabanmuntto/turvapaikanbakijat-ja-pakolaiset 19.1.2018

Tal, G. \& Handy, S. (2010) Travel behavior of immigrants: an analysis of the 2001 national household transportation survey. Transport Policy 17 85-93. https://doi.org/10.1016/j.tranpol.2009.11.003

Talen, E. (2002) The social goals of new urbanism. Housing Policy Debate, 13(1) 165-188. https://doi.org/10.1080 $/ 10511482.2002 .9521438$

THL = Terveyden ja hyvinvoinnin laitos (2017) Maahanmuuttajat ja monikulttuurisuus. Koulutus ja kielitaito. https:// www.thl.fi/fi/web/maahanmuuttajat-ja-monikulttuurisuus/maahanmuuttajien-osallisuus-ja-kotoutuminen/ koulutus-ja-kielitaito 19.1.2018

Tilastokeskus (2017) Maahanmuuttajat väestössä. http://www.stat.fi/tup/maahanmuutto/maahanmuuttajatvaestossa.html 24.1.2018

Toivonen, I. (2013) Maahanmuuttajien kokemuksia sopeutumisesta suomalaiseen yhteiskuntaan. Hyväksytty opinnäytetyö. Seinäjoen ammattikorkeakoulu. http://www.theseus.fi/bitstream/handle/10024/67827/toivonen_irina. pdf? sequence $=1$ \&is Allowed $=\mathrm{y}$

Tom, A. \& Denis, M. (2004) Language and spatial cognition: comparing the roles of landmarks and street names in route instructions. Applied Cognitive Psychology 18 1213-1230. https://doi.org/10.1002/acp.1045

Väestöliitto (2017) Maahanmuuttajien määrä. http://www.vaestoliitto.fi/tieto_ja_tutkimus/vaestontutkimuslaitos/ tilastoja/maahanmuuttajat/maahanmuuttajien-maara/ 19.2.2018

Vaittinen, T. \& McGookin, D. (2016) Phases of urban tourists' exploratory navigation: a field study. DIS' 16 Proceedings of the 2016 ACM Conference on Designing Interactive Systems, June 04 - 08, 2016, Brisbane, QLD, Australia, 1111-1122. http://dx.doi.org/10.1145/2901790.2901795

Wiener, J. M., Büchner, S. J. \& Hölscher, C. (2009) Taxonomy of human wayfinding tasks: a knowledge-based approach. Spatial Cognition \& Computation 9(2) 152-165. https://doi.org/10.1080/13875860902906496

Williams, C. H. \& Van Der Merwe, I. (1996) Mapping the multilingual city: a research agenda for urban geolinguistics. Journal of Multilingual and Multicultural Development, 17(1) 49-66. https://doi.org/10.1080/01434639608666259

Yu, S. (2016) "I'm like a deaf, dumb and blind person": mobility and immobility of Chinese (im)migrants in Flushing, New York City. Journal of Transport Geograpby 54 10-21. http://dx.doi.org/10.1016/j.jtrangeo.2016.05.004 